Abstracta Iranica Iranica

Revue bibliographique pour le domaine irano-aryen

Volume 32-33 | 2013

Comptes rendus des publications de 2009-2010

\title{
Giorgio Rota. La vita e i tempi di Rostam Khan (edizione e traduzione italiana del Ms. British Library Add 7,655)
}

\section{Christophe Werner}

\section{(2) OpenEdition}

1 Journals

Édition électronique

URL : http://journals.openedition.org/abstractairanica/40684

DOI : 10.4000/abstractairanica.40684

ISSN : 1961-960X

\section{Éditeur :}

CNRS (UMR 7528 Mondes iraniens et indiens), Éditions de l'IFRI

\section{Édition imprimée}

Date de publication : 1 décembre 2013

ISSN : 0240-8910

\section{Référence électronique}

Christophe Werner, « Giorgio Rota. La vita e i tempi di Rostam Khan (edizione e traduzione italiana del Ms. British Library Add 7,655) », Abstracta Iranica [En ligne], Volume 32-33 | 2013, document 256, mis en ligne le 01 juillet 2016, consulté le 26 septembre 2020. URL : http://journals.openedition.org/ abstractairanica/40684; DOI : https://doi.org/10.4000/abstractairanica.40684

Ce document a été généré automatiquement le 26 septembre 2020.

Tous droits réservés 


\title{
Giorgio Rota. La vita e i tempi di Rostam Khan (edizione e traduzione italiana del Ms. British Library Add $7,655)$
}

\author{
Christophe Werner
}

\section{RÉFÉRENCE}

Giorgio Rota. La vita e i tempi di Rostam Khan (edizione e traduzione italiana del Ms. British Library Add 7,655). Wien, Verl. der Österr. Akad. der Wiss., 2009, 432 p. (Phil.-Hist. Klasse Sitzungsberichte, 790 ; Veröffentlichungen zur Iranistik, 47).

1 Ce livre comporte la présentation, l'édition et la traduction d'une source "mineure » pour l'histoire safavide, mais néanmoins fascinante et importante, dont nous ne possédons à ce jour qu'un manuscrit unique. Cette chronique, datée de l'an 1104/1692, ne porte pas de titre. Elle est à la fois une biographie de Rostam Hुān Saak'adze (m. 1643), un officier ġolām assez important, et un récit (incomplet et sélectif) des certains évènements du règne de Šāh Șafī (r. 1629-1642). L'œuvre, rédigé par un certain Bīžan dont on n'a pas d'informations biographiques, mais dont on sait qu'il appartenait au « milieu des ġolām », a été dédiée au petit-fils de Rostam Hูān, Rostam Hูān « junior ».

L'introduction compte 30 pages environ, avec un court résumé en anglais. Elle est consacrée à la présentation du manuscrit, de l'A., du contenu et des sources de l'ouvrage, mais elle n'aborde pas le contexte de l'historiographie safavide d'une manière comparée. Pour les lecteurs non italophones - certainement la plupart des collègues iraniens -, il aurait été souhaitable que le texte persan soit éventuellement mis en page de façon plus attractive et lisible. Malgré cela, la présente édition et traduction mettent à notre disposition une source de plus sur l'époque safavide tardive, source qui nous donne l'accès à des informations de grande valeur, notamment en ce 
qui concerne la production des textes historiques à son époque, le règne de Šāh Șafī, ou les relations entre la Géorgie et l'Iran safavide.

\section{AUTEURS \\ CHRISTOPHE WERNER}

Philipps-Universität, Marburg 